\title{
United Kingdom Patent Decisions 2021
}

\section{Robyn Trigg}

Accepted: 1 February 2022 / Published online: 3 March 2022

(C) The Author(s) 2022

\begin{abstract}
This report highlights a selection of the most important UK patent decisions from 2021, including: one Supreme Court judgment concerning the economic tort of unlawful means, which importantly maintained the status quo for litigating patents in the UK; four Court of Appeal judgments (one concerning sufficiency and functional claiming, which overturned the decision below; two where the first instance finding was upheld; and one considering the crown use exception); and, seven High Court judgments (one giving obiter guidance on the Formstein defence in cases of infringement by equivalents; four relating to applications for expedition of proceedings; and two relating to FRAND and the effect of the ETSI undertaking).
\end{abstract}

Keywords Unlawful means - Sufficiency - Functional claiming - Crown use · Formstein defence · Expedition application · FRAND · ETSI undertaking

Cases Actavis v. Eli Lilly [2017] UKSC 48; [2018] 1 All ER 171; Abbott Laboratories Ltd v. Dexcom Incorporated [2021] EWHC 2246 (Pat); [2021] 8 WLUK 32; Advanced Bionics AG \& Anor v. MED-El Elektromedizinische Gerate [2021] EWHC 2415 (Pat); [2021] 9 WLUK 204; Facebook Ireland Ltd v. Voxer IP LLC [2021] EWHC 1377 (Pat); [2021] 5 WLUK 379; FibroGen Inc v. Akebia Therapeutics Inc [2021] EWCA Civ 1279; [2021] 8 WLUK 161; FibroGen Inc v. Akebia Therapeutics Inc [2020] EWHC 866 (Pat); [2020] 4 WLUK 194; Illumina Cambridge Ltd v. Latvia MGI Tech SIA \& Ors [2021] EWCA Civ 1924; [2021] 12 WLUK 235; Illumina Cambridge Ltd v. Latvia MGI Tech SIA \& Ors [2021] EWHC

R. Trigg $(\bowtie)$

DPhil Candidate, Magdalen College, University of Oxford, and Knowledge Lawyer at Osborne

Clarke LLP, London, UK

e-mail: robyn.trigg@law.ox.ac.uk 
57 (Pat); [2021] 1 WLUK 158; Interdigital Technology Corporation \& Ors v. Lenovo Group Ltd \& Ors [2021] EWHC 3401 (Pat); [2021] 12 WLUK 225; IPCom GmbH \& Co KG v. Vodafone Group Plc [2021] EWCA Civ 205; [2021] Bus LR 813; IPCom GmbH \& Co KG v. Vodafone Group Plc [2020] EWHC 132 (Pat); [2020] Bus LR 154; Neurim Pharmaceuticals (1991) Ltd \& Anor v. Generics UK Ltd (t/a Mylan) \& Anor [2021] EWHC 2198 (Pat); [2021] 8 WLUK 1; Nicoventures v. Philip Morris [2020] EWHC 1594 (Pat); [2020] 6 WLUK 226; OBG Ltd v. Allan [2007] UKHL 21; [2008] 1 AC 1; Optis Cellular Technology LLC \& Ors v. Apple Retail UK Ltd \& Ors [2021] EWHC 2564 (Pat); [2021] 9 WLUK 276; Regeneron $v$. Genentech [2013] EWCA Civ 93; [2013] 2 WLUK 607; Regeneron Pharmaceuticals Inc v. Kymab Ltd [2020] UKSC 27; [2021] 1 All ER 475; Secretary of State for Health \& Anor v. Servier Laboratories Ltd \& Ors [2021] UKSC 24; [2021] 3 WLR 370; Secretary of State for Health \& Anor v. Servier Laboratories Ltd \& Ors [2017] EWHC 2006 (Ch); [2017] 8 WLUK 19; Secretary of State for Health \& Anor v. Servier Laboratories Ltd \& Ors [2019] EWCA Civ 1160 see this issue of IIC at https://doi.org/10.1007/s40319-022-01168-9; [2020] Ch 717; Teva Pharmaceutical Industries Ltd \& Anor v. Janssen Pharmaceutica NV [2021] EWHC 1922 (Pat); Unwired Planet International Ltd v. Huawei Technologies Co Ltd [2017] EWHC 1304; [2017] 6 WLUK 60; WL Gore and Associates GmbH v. Geox SpA [2008] EWCA Civ 622; [2008] 3 WLUK 467; Wyeth LLC v. Merck Sharp \& Dohme (UK) Ltd [2021] EWCA Civ 1099; [2021] 7 WLUK 337; Wyeth LLC v. Merck Sharp \& Dohme (UK) Ltd [2020] EWHC 2636 (Pat); [2020] 10 WLUK 132.

\section{Legislation Patents Act 1977}

Other Agreement on Trade-Related Intellectual Property Rights (TRIPS); Civil Procedure Rules; ETSI Intellectual Property Rights Policy; European Patent Convention; Practice Statement: Listing of Cases for Trial in the Patents Court

\section{Introduction}

Despite the global pandemic, patent litigation in England and Wales continued to be active in 2021. The courts remained adaptable and flexible, with some cases being heard fully remotely, others entirely in person, and others in a hybrid format. A wide range of topics were litigated in 2021 - too many to cover here. This review article will focus on a selection of the most notable decisions from the Supreme Court, Court of Appeal, and Patents Court over the past 12 months.

\section{IPCom GmbH \& Co KG v. Vodafone Group Plc}

The year kicked off with IPCom GmbH \& Co KG v. Vodafone Group Plc. ${ }^{1}$ The Court of Appeal took up an appeal of this standard essential patent (SEP) technical

\footnotetext{
$\overline{1}$ [2021] EWCA Civ 205; [2021] Bus LR 813.
} 
trial, heard at first instance last year. ${ }^{2}$ IPCom's patent in issue here related to a method for allocating mobile devices access rights to particular telecommunications channels at particular times. At first instance, Recorder Douglas Campbell QC found IPCom's patent (in amended form) to be valid and essential, and that certain of Vodafone's acts had infringed it. ${ }^{3}$

However, Vodafone had successfully deployed the Crown use defence in the context of some of the acts it had undertaken. ${ }^{4}$ The judge found that Vodafone's use of the patented method for controlling network access when responding to requests via the Mobile Telecommunications Privileged Access Scheme (MTPAS) fell within the scope of the little used defence. ${ }^{5}$

Both parties appealed the first instance decision. IPCom challenged the judge's finding that some of Vodafone's acts did not infringe and that others were covered by the Crown use defence. ${ }^{6}$ Whereas Vodafone challenged the judge's construction of the conditionally amended claims (referred to as the appeal on "set up to send"), which underpinned his findings of validity and infringement, and also the judge's finding of essentiality. ${ }^{7}$

The Court of Appeal (leading judgment given by Arnold LJ, with some additional comments from Lewison LJ) dismissed Vodafone's appeal on the findings of validity, infringement, and essentiality. ${ }^{8}$ IPCom's appeal on Recorder Campbell QC's construction of the conditionally amended claims was also dismissed. ${ }^{9}$ However, the Court of Appeal overturned the first instance finding with respect to Vodafone's use of the Crown use defence. ${ }^{10}$

The remainder of this summary will focus on this aspect of the appeal. The consequence of the judge's finding below with respect to the Crown use defence was that compensation payable to IPCom would have been payable by the relevant Government department rather than by Vodafone. Both IPCom and the Secretary of State for Defence contended that the judge fell into error when construing Sec. 55(1) of the Patents Act 1977 (PA 1977). The issue turned on what was meant by "authorised in writing by a government department" and what form of authorisation was required for this purpose. ${ }^{11}$

\footnotetext{
2 [2020] EWHC 132 (Pat); [2020] Bus LR 154. See last year's case summary for further details at https:// doi.org/10.1007/s40319-021-01036-y.

3 On construction, see supra note 2, [69]-[93]; on added matter see supra note 2, [95]-[123]; on obviousness over the prior art see supra note 2, [124]-[141]; on essentiality see supra note 2, [142][180]; on infringement see supra note 2, [181]-[242]; on Vodafone's application for declarations of noninfringement see supra note 2, [243]-[248]; and for conclusion see supra note 2, [249].

4 Sections 55-59 PA 1977.

5 Supra note 2, [209]-[212].

6 Supra note 1, [4].

7 Ibid.

8 Supra note 1, [210], [224].

9 Supra note 1, [210]. Note that Lewison LJ expressed some concerns about this finding but he did not "push [his] doubts to a dissent" (see supra note 1, [212]-[223]).

10 Supra note 1, [210], [224].

11 Supra note 1, [120].
} 
Three possible interpretations of "authorised in writing by a government department" were put before the first instance judge: (i) it requires an express authorisation to work the patent in question; (ii) it requires either an express authorisation to work the patent in question or an authorisation to do a particular act in circumstances where that act necessarily infringes the patent; or (iii) it extends to an authorisation to do a particular act even if that does not necessarily involve infringing the patent. ${ }^{12}$ At trial, Vodafone supported the third interpretation and IPCom supported the second. Recorder Campbell QC agreed with Vodafone that the third interpretation was the correct one. On appeal, IPCom contended that the first interpretation was the correct one, save that the Secretary of State for Defence maintained that an express authorisation to work any patent will suffice.

The Court of Appeal overturned the judge below. Arnold LJ held that the third interpretation was not correct and that Vodafone did not have a defence of Crown use in respect of MTPAS. ${ }^{13}$ Arnold LJ noted that it was not "strictly necessary" for the purpose of the appeal to decide whether the first or second interpretation was correct but nevertheless stated that his opinion was that the second interpretation was preferential. $^{14}$

Arnold LJ set out 13 reasons for coming to the conclusion that the second interpretation was most favourable, including, for example: it being the most natural interpretation of the language of the statute; it being consistent with the law of agency; the weight of past decisions favouring his approach; it placing less of a burden on the Crown; and it being consistent with the UK's international obligations under Art. 31 of the Agreement on Trade-Related Intellectual Property Rights (TRIPS). ${ }^{15}$

The first instance decision in this case had potentially opened the door to seeing an increased use of the Crown use defence in telecoms patent litigation. However, with the Court of Appeal overturning this aspect of the judgment and favouring a more narrow interpretation of the defence, it is likely that the potential instances for its deployment are greatly lessened. Clarity has been provided that the requirement of needing written authorisation by a government department in Sec. 55(1) PA 1977 means either an express authorisation to work a patent or an authorisation to do a particular act in a situation where that act necessarily infringes the patent, rather than more broadly extending to an authorisation covering acts that do not necessarily involve infringing the patent.

\footnotetext{
9 Supra note 1, [210]. Note that Lewison LJ expressed some concerns about this finding but he did not "push [his] doubts to a dissent" (see supra note 1, [212]-[223]).

${ }^{10}$ Supra note 1, [210], [224].

11 Supra note 1, [120].

12 Supra note 1, [147].

13 Supra note 1, [149], [173].

14 Supra note 1, [149].

15 Supra note 1, [150]-[173], in particular [150], [151], [152], [159], [165].
} 


\section{Facebook Ireland Ltd v. Voxer IP LLC}

In Facebook Ireland Ltd v. Voxer IP LLC, ${ }^{16}$ proceedings were initially started by Facebook as an action for revocation of one of Voxer's patents. ${ }^{17}$ Voxer then counterclaimed for infringement, arguing that Facebook infringed its patent by offering a live broadcast feature on Facebook and Instagram. Voxer relied on the doctrine of equivalents in relation to two claim integers, and made two amendment applications. ${ }^{18}$ Facebook denied infringement and contended that the patent was invalid. On Voxer's claim of infringement by equivalents, Facebook also maintained that it had a Formstein defence. ${ }^{19}$ Both Facebook and the Comptroller objected to Voxer's proposed amendments on the basis of added matter and lack of clarity. ${ }^{20}$ The case was tried under the Shorter Trials Scheme. ${ }^{21}$

Birss LJ (sitting as a High Court Judge) ultimately found that Voxer's patent was not infringed by any of Facebook's live broadcast features. Voxer's proposed amendments to its patent were accepted, with Facebook and the Comptroller's objections being dismissed. However, the amended patent was found to be invalid for obviousness over a US patent application. The most interesting aspect of the decision was, however, Birss LJ's obiter comments on the use of the Formstein defence in circumstances of infringement by equivalents. ${ }^{22}$

The now famous Supreme Court decision of Actavis v. Eli Lilly ${ }^{23}$ set out how the doctrine of equivalents should be applied in UK law in the context of infringement. However, that case was limited to infringement issues and therefore questions remain about how the doctrine of equivalents should be applied in the invalidity context. Formstein was a German case in which equivalents were considered by the infringement court. Rather than finding the patent in suit invalid, the court limited the patent's claim to its normal construction. The Formstein defence effectively applies the well-established Gillette defence to infringement to circumstances where the doctrine of equivalents applies.

In deploying a Gillette defence, an alleged infringer argues that their activities would have either lacked novelty or been obvious at the patent in suit's priority date. This means that either the patent is held to be valid but not infringed or, alternatively, if the alleged infringement falls within the scope of the patent in suit, it must be invalid.

Following Actavis, if the court finds that the patent in suit is valid but not infringed on its normal construction, it must go on to consider infringement by equivalents. This prompts the question: what happens if a product is found to infringe by equivalents only but it is also held to be obvious over the prior art?

\footnotetext{
16 [2021] EWHC 1377 (Pat); [2021] 5 WLUK 379.

17 Supra note 16, [1].

18 Supra note 16, [5].

19 Ibid.

${ }^{20}$ Supra note 16, [3].

21 Supra note 16, [1].

22 Supra note 16, [209]-[217].

23 [2017] UKSC 48; [2018] 1 All ER 171.
} 
The UK courts have previously acknowledged this issue and suggested that a Formstein defence might apply. Although Birss LJ did not need to decide this point, he did provide useful obiter guidance on the matter. In his view, the correct approach is to confine the patent's claim to its normal construction and hold the claim to be valid but not infringed, rather than infringed but invalid. Indeed, this was the approach taken in Formstein itself and has also been followed in the Netherlands and the USA. ${ }^{24}$

The judge thought this was the correct approach as: (i) it would be harsh to invalidate a claim that was valid on a normal construction and it promotes certainty in allowing patentees to write their claims such that they do not cover the prior art on a normal construction; and (ii) other European Patent Convention (EPC) countries have adopted that approach and therefore the UK, as another EPC state, should take the same approach. ${ }^{25}$

Although Birss LJ's comments were only obiter and are therefore not binding, they provide a good insight into how the UK courts might deal with a Formstein defence should it need to be applied in the context of infringement by equivalents.

\section{Secretary of State for Health \& Anor v. Servier Laboratories Ltd \& Ors}

Although Secretary of State for Health \& Anor v. Servier Laboratories Ltd \& Ors ${ }^{26}$ principally concerned the unlawful means economic tort and not patent litigation directly, the Supreme Court's decision on the matter had the potential to upend the entire system of patent litigation in the UK. This, however, did not come to pass and the status quo was maintained.

The case concerned an appeal brought by the Secretary of State for Health and the NHS Business Services Authority (the Appellants) against Servier. The Appellants fund the cost of medicines dispensed by the NHS in England. Servier developed and manufactured a drug for the treatment of cardiovascular disease marketed as "Coversyl". 27

In 2001, Servier applied to the European Patent Office (EPO) for a patent, which was granted, including a UK designation, in 2004. Opposition proceedings were brought against the patent, which was upheld by the EPO's Opposition Division in $2006 .^{28}$

Servier sought to enforce the UK designation in the English courts and obtained preliminary injunctions against competitors who wanted to launch generic versions of its drug. The generics counterclaimed for invalidity and were successful at trial in 2007. The invalidity decision was upheld by the Court of Appeal in 2008 and in

\footnotetext{
24 Supra note 16, [216].

25 Supra note 16, [216].

26 [2021] UKSC 24; [2021] 3 WLR 370.

27 Ibid, see [6]-[14] for background facts.

28 Ibid.
} 
2009 the EPO's Technical Board of Appeal revoked the patent. The Appellants had not been involved in the proceedings at the EPO or the English courts. ${ }^{29}$

The Appellants argued that in obtaining, defending, and enforcing the UK patent, Servier had practised deceit on the EPO and/or the English courts (the third parties) with the intention of profiting at the Appellants' expense. ${ }^{30}$ The Appellants contended that as a consequence of this alleged deceit, generic versions of the drug did not enter the market as early as they otherwise would have, which caused drug prices to be higher. This deceit formed the basis of the appellants' claim for an unlawful means tort and they sought damages and interest in excess of $£ 200 \mathrm{~m} .{ }^{31}$

In August 2017, the High Court struck out the Appellants' claim. ${ }^{32}$ The Appellants appealed the decision and, in July 2019, the Court of Appeal dismissed their appeal. ${ }^{33}$ The High Court and the Court of Appeal held that the House of Lords, in its decision of OBG Ltd v. Allan, ${ }^{34}$ had concluded that an essential element of the tort of causing loss by unlawful means was that the unlawful act intended to cause loss to the claimant by interfering with the freedom of a third party in a way that was unlawful and that affected the third party's freedom to deal with the claimant. Therefore, the High Court and the Court of Appeal decided that $O B G$ determined that a "dealing requirement" was a necessary component of the tort, and they were bound to follow that precedent.

Before the Supreme Court, the Appellants averred that the dealing requirement should not be a necessary element of the tort as it did not form part of the ratio of the $O B G$ decision or, alternatively, the Supreme Court should depart from $O B G$ and remove the dealing requirement. ${ }^{35}$

The Supreme Court unanimously agreed with the lower courts that the dealing requirement did form part of the ratio of $O B G .{ }^{36}$ Lord Hamblen noted the policy issues considered by Lord Hoffmann in $O B G$ as providing a background for this finding. He particularly pointed to the rationale of the tort being to preserve a person's liberty to deal with others and the concern that the tort should not be too expansive, which could be best achieved by giving a narrow meaning to "unlawful means" by including the dealing requirement. ${ }^{37}$

Consequently, the Supreme Court ruled that by defending and enforcing a patent that was later determined to be invalid, Servier did not commit the tort of causing loss by unlawful means. ${ }^{38}$

This case saw the Supreme Court reject the Appellants' attempt to bring allegations of fraud on the patent office that exist in other jurisdictions (for example,

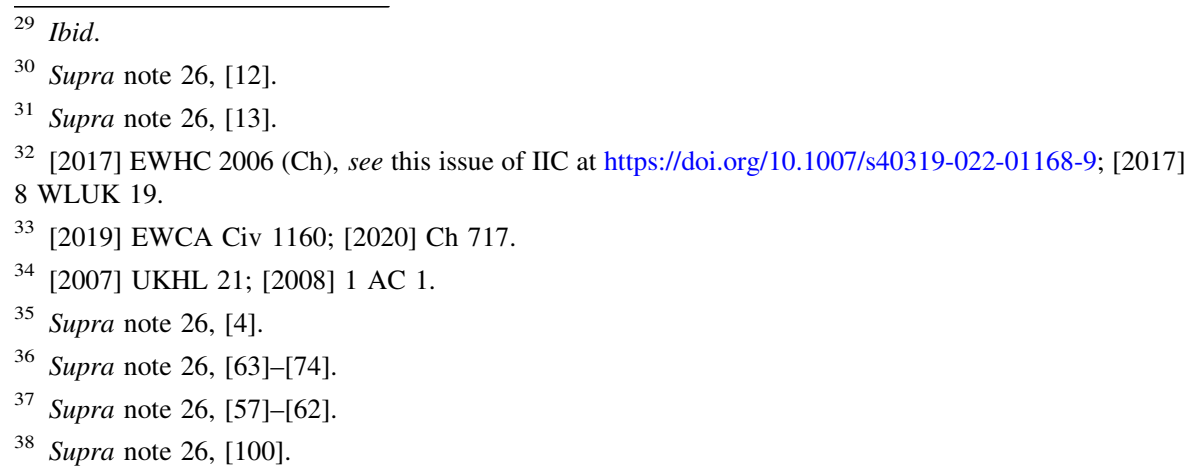


the USA) within the tort of unlawful means. The Supreme Court unanimously held that the dealing requirement was part of the ratio of the $O B G$ decision and the Appellants failed to demonstrate a sufficiently good reason for it to depart from that decision. The patentee, therefore, avoided liability for the economic loss suffered, in this case by the NHS, because generics were only able to enter the market later than if the patent had not been in force. While this decision could have had a seismic impact on the overall landscape of patent litigation in the UK, the Supreme Court opted to maintain the status quo position and eradicated the opportunity to seek redress by parties tangentially related to patent validity proceedings but who are financially impacted by a finding that a patent is invalid.

\section{Wyeth LLC v. Merck Sharp \& Dohme (UK) Ltd}

Next, in Wyeth LLC v. Merck Sharp \& Dohme (UK) Ltd, ${ }^{39}$ the Court of Appeal considered an appeal from Wyeth concerning a first instance judgment of Meade J. ${ }^{40}$ At first instance, Meade J had held that Wyeth's vaccine formulation patent was invalid on the basis of obviousness over a prior art research paper and, in any event, Merck Sharp \& Dohme's (MSD) vaccine would not infringe any claim of Wyeth's patent even if valid. ${ }^{41}$

In the Court of Appeal, Arnold LJ gave the leading judgment and Sir Christopher Floyd gave some additional comments. Arnold LJ reminded that obviousness assessments involve a multi-factorial evaluation. Thus, the Court of Appeal is not justified in intervening with a trial judge's decision in the absence of an error of law or principle. $^{42}$

Wyeth had argued that Meade $\mathrm{J}$ had erred in principle because he misinterpreted the prior art research paper. ${ }^{43}$ However, Arnold LJ held that the judge had not made any material errors in this regard and he was correct in holding that the claims were obvious. $^{44}$

Sir Christopher agreed with Arnold LJ, adding that obviousness cases can be rejected on the basis that, with the passing of time, a prior art document becomes a "dead end as opposed to a useful starting point for further development". ${ }^{45}$ But, such treatment of a prior art document must be supported by evidence that this is how the skilled person would have treated the document in question based on their common general knowledge. ${ }^{46}$

Wyeth had argued that as the relevant prior art had been published in 2004, two years before the patent's priority date, the question for the judge was what would the

\footnotetext{
39 [2021] EWCA Civ 1099; [2021] 7 WLUK 337.

40 [2020] EWHC 2636 (Pat); [2020] 10 WLUK 132.

41 Ibid, [366].

42 Supra note 39, [28].

43 Supra note 39, [29] et seq.

44 Supra note 39, [29]-[39].

45 Supra note 39, [42].

46 Ibid.
} 
reaction of the skilled person have been at the priority date, in light of the common general knowledge as it stood at that time. ${ }^{47}$ Wyeth pointed to failures in Phase III clinical trials by two other commercial undertakings, Sanofi and GSK, as evidence that the disclosure in the prior art would not be worth progressing. ${ }^{48}$

However, Sir Christopher noted that Meade J below had found that the difficulties encountered by Sanofi and GSK were specific to those companies and not innate to the task at hand. These difficulties therefore, would not have provided a reasoned disincentive to progress the vaccine disclosed in the prior art, which was disclosed to be in advanced studies by Wyeth. ${ }^{49}$

In the absence of any evidence that Wyeth had encountered similar difficulties with respect to its vaccine, the skilled person would have been entitled to assume that Wyeth was still actively pursuing its vaccine at the priority date in 2006, as it had said it was doing in $2004 .^{50}$ Unless the common general knowledge supported the idea that Wyeth's vaccine had innate problems, which it was found it did not, the prior art would still have given the skilled person sufficient motivation to progress making a formulation falling within the scope of the patent. ${ }^{51}$

This decision provided a strong reminder of the multi-factorial nature of obviousness assessments and that the Court of Appeal will only intervene with a trial judge's findings if there has been an error of law or principle, which was not found to be the case here.

\section{Expedition Applications}

As well as being a bumper year for cases considering substantive issues of patent law, 2021 also saw a number of noteworthy procedural decisions. Over the course of the summer, there was a spate of applications seeking expedition of proceedings in the Patents Court, which called into question whether it is becoming more frequent and easier to speed up proceedings in the UK.

The Patents Court aims, where possible, to list patent trials within 12 months of a claim being issued. ${ }^{52}$ However, the courts have general powers of case management, which include the ability to bring forward a hearing, afforded by the Civil Procedure Rules (CPRs). ${ }^{53}$ The courts have previously held that expedition would only be justified if there was objective urgency and pressing reasons justifying the prioritisation of one case over others in the court's list. However, the success of a number of the applications made in 2021 might well indicate the court's willingness

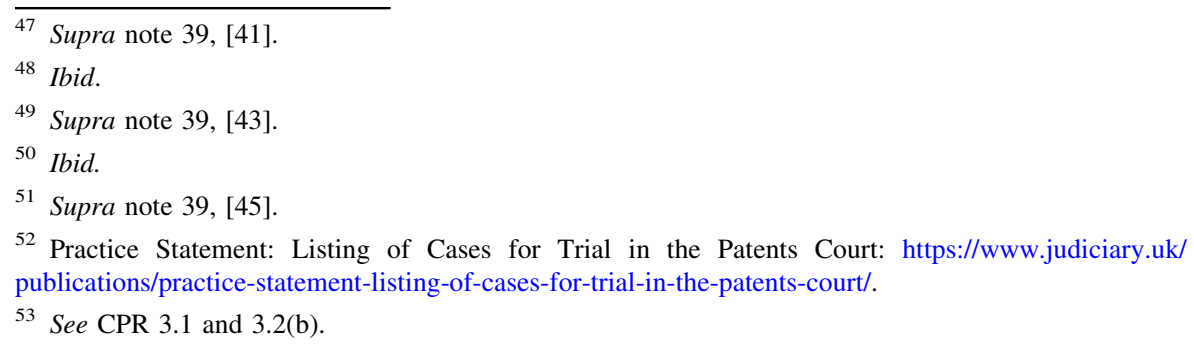


to consider and grant expedition in a broader range of circumstances than previously believed to be the case.

Historically, the courts have laid down a range of factors to be taken into account when considering expedition applications. The Court of Appeal laid down four factors in WL Gore and Associates GmbH v. Geox $\operatorname{SpA},{ }^{54}$ whether: (i) the applicants have shown good reason for expedition; (ii) expedition would interfere with the good administration of justice; (iii) expedition would cause prejudice to the other party; and (iv) there are any other special factors (including the conduct of the applicant and whether they have caused any unnecessary delays). ${ }^{55}$

Three additional points relevant to patent cases were made by Birss $\mathbf{J}$ (as he then was) in Nicoventures $v$. Philip Morris: ${ }^{56}$ (i) expedition applications involve a level of "queue-jumping" and therefore must be properly justified; (ii) the mere wish for commercial certainty is not alone enough to justify expedition; and (iii) the desire to avoid the German "injunction gap" is a factor to be taken into account by the courts but alone is not enough to tip the balance in favour of expedition. ${ }^{57}$ The German injunction gap arises from the bifurcated system in Germany, where infringement proceedings are held separately to validity proceedings and are often undertaken more quickly - and can be enforced, including by injunction, before a validity finding is made.

The four expedition decisions from 2021 build upon this background.

\subsection{Teva Pharmaceutical Industries Ltd \& Anor v. Janssen Pharmaceutica NV}

This short decision Teva Pharmaceutical Industries Ltd \& Anor v. Janssen Pharmaceutica $N V^{58}$ concerned an application to expedite a patent trial relating to a then newly granted patent for a dosing regimen for the drug paliperidone. Meade $\mathbf{J}$ considered the Gore factors and held that the trial could be expedited to a degree that would bring the timetable in-line with the Patents Court's one-year trial target with "only minor disruption". 59 The judge held that Teva had demonstrated a need for commercial certainty that the expedited proceedings would provide, without prejudice to Janssen. ${ }^{60}$ He noted that Janssen was being tactically "cagey" about whether it would apply for interim relief, which resulted in him making a decision based on imperfect information. ${ }^{61}$ The judge allowed the application and permitted a degree of expedition. ${ }^{62}$ In coming to that decision, he stressed that the issue of

\footnotetext{
54 [2008] EWCA Civ 622; [2008] 3 WLUK 467.

55 Ibid, [25].

56 [2020] EWHC 1594 (Pat); [2020] 6 WLUK 226.

57 Ibid, [11]-[14].

58 [2021] EWHC 1922 (Pat).

59 Ibid, [3].

60 Supra note 58, [8].

61 Supra note 58, [10].

62 Supra note 58, [14].
} 
expedition exists on a "sliding scale", with certain reasons justifying a moderate degree of expedition and others supporting a greater degree. ${ }^{63}$

\subsection{Neurim Pharmaceuticals (1991) Ltd \& Anor v. Generics UK Ltd (t/a Mylan) \& Anor}

This dispute in Neurim Pharmaceuticals (1991) Ltd \& Anor v. Generics UK Ltd (t/a Mylan) \& Anor ${ }^{64}$ concerned a divisional patent for the use of melatonin as a treatment for primary insomnia. The expedition application related to various preliminary issues including estoppel arguments concerning previous litigation involving the parent patent. The judge referred to the Gore factors and noted four "special factors" falling into the scope of the fourth Gore factor that he had taken into consideration, being that: (i) Neurim had a prima facie valid patent; (ii) it appeared that Mylan's marketed product infringed the patent; (iii) the patent was close to expiry and this final period is often particularly valuable for a patentee; and (iv) there were estoppel "arguments to be had" against Mylan. ${ }^{65}$ These special factors and what the judge called the "unusual circumstances" of the case (a preliminary injunction had not been granted despite Mylan having failed to clear the path) meant that "a moderate degree" of expedition was granted on the preliminary issues, this being "the only realistic way in which Neurim can hope to secure injunctive relief before expiry of [the patent in suit]". ${ }^{66}$

\subsection{Abbott Laboratories Ltd v. Dexcom Incorporated}

The case Abbott Laboratories Ltd v. Dexcom Incorporated ${ }^{67}$ concerned revocation proceedings for four Abbott patents relating to various features of continuous glucose monitoring devices for managing diabetes. Although commercial certainty was an important reason put forward for expedition, the primary reason was held to be to try to avoid the problems caused by the German injunction gap. The former issue was held to be not a "particularly powerful" reason for expedition. ${ }^{68}$ The latter was a significant factor, but could not alone justify expedition. ${ }^{69}$ The fact that there were separate UK proceedings involving eight Dexcom patents and to grant expedition only in respect of the trial involving the Abbott patents would have created a timing asymmetry also appears to have been an important reason for refusing expedition. ${ }^{70}$

\footnotetext{
63 Supra note 58, [6].

64 [2021] EWHC 2198 (Pat); [2021] 8 WLUK 1.

65 Ibid, [40].

66 Supra note 64, [45].

67 [2021] EWHC 2246 (Pat); [2021] 8 WLUK 32.

68 Ibid, [55].

69 Supra note 67, [56]-[57].

70 Supra note 67, [58].
} 


\subsection{Advanced Bionics $A G$ \& Anor v. MED-El Elektromedizinische Gerate}

Like Abbott, Advanced Bionics AG \& Anor v. MED-El Elektromedizinische Gerate $^{71}$ was also part of international proceedings involving the US and Germany as well as the UK. It also concerned issues of commercial certainty and the German injunction gap. Interestingly, however, in Advanced Bionics the judge decided in favour of expedition. The main reason for the different outcome was that Advanced Bionics was able to demonstrate that the German injunction gap would have an adverse effect on the UK market for cochlear implants, the subject matter of the patent. ${ }^{72}$ Other factors that appear to have played an important part in the judge's reasoning are that the case involved a single patent (rather than the four (or arguably eight) in suit in Abbott), for technology that the judge considered to be less complex, and there was also only a single prior art citation. ${ }^{73}$ Mellor $\mathrm{J}$ also found that MED-El would not be adversely affected by the expedition and that the expedited listing ordered could slot into the Patents Court diary without actively displacing any other litigant. ${ }^{74}$

These recent expedition cases confirm that the question of whether to grant expedition and, if so, the amount of expedition is not binary. Rather, these issues exist on a sliding scale and are impacted by external factors, such as the number of other concurrent proceedings and whether other litigants who have already begun proceedings will be actively displaced by the expedition. The state of the Patents Court diary and the desire for speed seem to have been highly relevant factors in these decisions, perhaps more so than in the past.

Although the precise impact these decisions will have on the speed of UK patent proceedings is not yet clear, what is certain is that the UK courts are prepared to entertain applications for expedition and remain determined to ensure that patent disputes continue to be heard promptly. But, given the success of a number of these recent expedition applications, it seems likely that more similar requests will be made in the future.

\section{FibroGen Inc v. Akebia Therapeutics Inc}

Moving away from these procedural decisions and back to substantive patent law, next up we had an important Court of Appeal decision FibroGen Inc v. Akebia Therapeutics $I n c,{ }^{75}$ which overturned a first instance judgment from Arnold LJ (sitting as High Court Judge) relating to the sufficiency of claims with structural features and functional requirements. ${ }^{76}$ This case related to six patents belonging to FibroGen (which were exclusively licensed to Astellas). The patents formed two

\footnotetext{
71 [2021] EWHC 2415 (Pat); [2021] 9 WLUK 204.

72 Ibid, [74].

73 Supra note 71, [22].

74 Supra note 71, [69].

75 [2021] EWCA Civ 1279; [2021] 8 WLUK 161.

76 [2020] EWHC 866 (Pat); [2020] 4 WLUK 194.
} 
families (A and B) relating to claims for the treatment of certain types of anaemia using compounds defined in structural and functional terms.

At first instance, Arnold LJ held that the patent was implicitly promising that substantially all of the compounds that satisfied the structural definitions in the claims would have the claimed therapeutic effect. ${ }^{77}$ Accordingly, he held that the claims were insufficient because: (i) it was not plausible that substantially all of the compounds covered by the structural definition in the claims would have the claimed therapeutic effect; and (ii) it would be a substantial research project to identify any compounds other than those specifically identified in the specification; therefore, the invention could not be performed across the scope of the claims without undue burden. ${ }^{78}$

The Court of Appeal (the leading judgment was given by Birss LJ, with additional comments on sufficiency from Sir Christopher Floyd) overturned the first instance decision. Birss LJ set out a new three-step structured approach for considering the sufficiency of claims with structural and functional features. ${ }^{79}$

Firstly, one must identify what falls within the scope of the claimed class. Secondly, one must determine what it means to say that the invention works - that is, what is the invention for? ${ }^{80}$ With respect to these first two steps, Birss LJ said that it is necessary to distinguish between two types of functional limitations: (i) those limiting the claimed class of compounds (Birss LJ gave an example from Regeneron v. Genentech ${ }^{81}$ of VEGF (vascular endothelial growth factor) antagonism); and (ii) those relating to the desired effect (such as treating the relevant disease) ${ }^{82}$

Once these stages have been determined, one can move on to the crucial third stage of answering the question: is it possible to make a reasonable prediction that the invention will work with substantially everything falling within the scope of the claim? The judge stated that he preferred the language of "reasonable prediction" rather than "plausibility" but that it is "the same principle". 83

Moving on to the issue of undue burden, Birss LJ also disagreed with Arnold LJ below, holding that the appropriate question is whether it is possible to perform the invention across the scope of the claim without undue burden (rather than requiring the skilled person to identify substantially all compounds covered by the claim without undue burden). ${ }^{84}$

For claims like those in this case, the judge held that this question has two elements. Firstly, it must be possible for the skilled person to identify "some other

\footnotetext{
77 Ibid, [376].

78 Supra note 76, [399].

79 Supra note 75, [53].

80 Ibid.

81 [2013] EWCA Civ 93; [2013] 2 WLUK 607.

82 Supra note 75, [54]-[58].

83 Supra note 75, [52].

84 Supra note 75, [61] et seq.
} 
compounds", beyond those named in the patent, that are within the claimed class and are therefore likely to have therapeutic efficacy. ${ }^{85}$ Secondly, separately, it must also be possible for the skilled person to work substantially anywhere within the whole claim. Birss LJ said that this would involve the skilled person, when given a sensible compound within the structural class (or substantially any), being able to apply the tests without undue burden and work out if it is a claimed compound. ${ }^{86}$

Beyond Birss LJ's leading judgment, Sir Christopher also gave a short judgment on the issue of sufficiency because "we are differing from a patent judge of enormous experience and distinction ...". ${ }^{87}$ Sir Christopher held that functional requirements of claims would be "otiose" if only compliance with structural formula was all that was necessary to achieve the therapeutic effect. Thus, it is only compounds that meet the particular functional requirements of a claim that the skilled person would understand to have the predicted therapeutic effect. $^{88}$ The judge also held that Arnold LJ's approach to claim construction below meant that his conclusion on plausibility was "inevitable". But on the correct construction of the claims, that is, they are limited by both the structural and functional features, "the question of plausibility answered itself". ${ }^{89}$

Consequently, the appeal on the sufficiency of the Family A patents (both on the breadth of claim and uncertainty) was allowed, at least in relation to one particular patent. That patent was held to be valid and would be infringed by Akebia's product. ${ }^{90}$ Even though the sufficiency findings also applied to the Family B patents, the finding of obviousness with respect to those patents was upheld and therefore they remained invalid. ${ }^{91}$

This decision was far more patentee-friendly than Arnold LJ's first instance decision. Importantly, it reinstated the limiting effect of functional requirements. Birss LJ's structured approach to considering the sufficiency of claims with structural and functional features provides a new, more practical way of dealing with such issues. Even though Birss LJ's approach to undue burden leaves open the question of what amounts to "some other compounds" within the claimed class beyond those identified in the patent, it sets in place a lower standard for undue burden than had previously been determined by Arnold LJ below. It also places the essence of what the invention is for at the centre of the analysis, allowing the issue of functional claiming to be considered in a more real-world context.

\footnotetext{
85 Supra note $75,[121]$.

86 Ibid.

87 Supra note 75, [284].

88 Supra note 75, [288].

89 Supra note 75, [290].

90 Supra note 75, [281].

91 Supra note 75, [282].
} 


\section{Optis Cellular Technology LLC \& Ors v. Apple Retail UK Ltd \& Ors}

Next in Optis Cellular Technology LLC \& Ors v. Apple Retail UK Ltd \& Ors ${ }^{92}$ we returned to SEPs, in another instalment of the multi-patent action between Optis and Apple. This trial was referred to as Trial $\mathrm{F}$ and Optis sought an injunction against Apple in respect of a patent that had been found in an earlier trial to be valid and infringed. ${ }^{93}$ Without getting bogged down by the detail of this complex and lengthy judgment, Meade $\mathrm{J}$ ultimately held that an implementer must commit to taking a FRAND licence in order to rely on the SEP holder's ETSI undertaking and thereby avoid being injuncted once a UK SEP has been found valid and infringed in the UK courts. $^{94}$

It is not enough for an implementer to state that they might take a licence in the future once the terms have been determined by the court at the FRAND trial if the implementer intends to continue operating in the UK. ${ }^{95}$ The implementer must commit to taking the court-determined licence in advance of the FRAND trial.

As Apple had not so committed, it was found to not be able to rely on Optis' ETSI undertaking under clause 6.1 of the ETSI Intellectual Property Rights Policy (ETSI IPR Policy). ${ }^{96}$ Meade J, however, allowed Apple to have " $a$ short time" to consider whether it wished to commit to taking the FRAND licence or whether to offer some other kind of undertaking. ${ }^{97}$ The judge held that he would consider whether in fact to grant the injunction once Apple had considered the judgment and its position. ${ }^{98}$

It was held that the appropriate form of the injunction Apple is liable to have imposed upon it is a FRAND injunction, i.e. it is of the normal form to restrain infringement of the relevant patent(s) and includes a proviso that it will cease to have effect if a FRAND licence is entered into. ${ }^{99}$

\section{Interdigital Technology Corporation \& Ors v. Lenovo Group Ltd \& Ors}

Later, in Interdigital Technology Corporation \& Ors v. Lenovo Group Ltd \& Ors ${ }^{100}$ we had another SEP matter attempting to build on Meade J's finding in Optis $v$. Apple. ${ }^{101}$ In that case, Meade $\mathrm{J}$ had held that an implementer must commit to taking a court-determined FRAND licence in order to avoid being injuncted once a UK

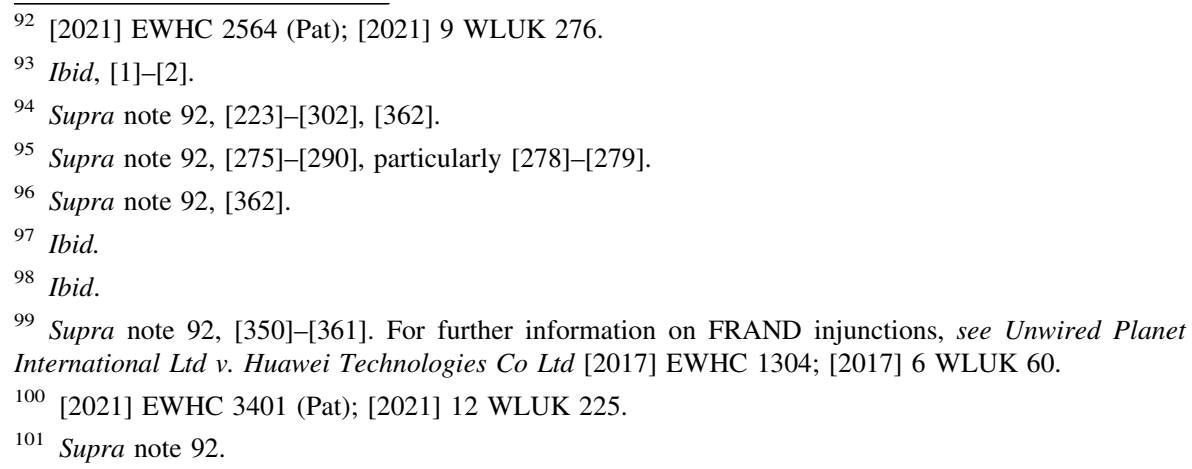


SEP has been found valid, essential, and infringed. Apple had been found not to be able to rely on Optis' ETSI undertaking unless it committed to entering into a FRAND licence.

Building on this, here, Interdigital sought a declaration that Lenovo could not rely on its ETSI undertaking and an injunction to prohibit infringement of its patent previously found to be valid, essential, and infringed. ${ }^{102}$ Interdigital argued that Meade $\mathrm{J}$ had determined in Optis that an injunction should be granted and that should follow here. This declaration and injunctive relief were sought ahead of the FRAND trial scheduled to be heard at the beginning of 2022.

The judge framed the core issue as follows: " $[\mathrm{t}]$ he real question I have to resolve is whether, as InterDigital submit, the grant of the injunction they seek follows inexorably from the Optis Injunction Judgment or whether, as Lenovo submit, it depends in significant part on matters not considered by Meade $\mathrm{J}$ which can only be resolved at the FRAND trial". 103

HHJ Hacon considered the Optis judgment in depth, ${ }^{104}$ concluding that the principles of French law (the governing law of the ETSI IPR Policy) found by Meade $\mathrm{J}$ were made on the basis that the English court was the only tribunal that could determine a global FRAND licence. ${ }^{105}$ The judge held that Meade J had had no reason to decide whether it would make a difference if an implementer were to give an unqualified commitment to taking a FRAND licence to be settled by another court in another jurisdiction and, if so, the extent to which the SEP owner had agreed to this. HHJ Hacon confirmed that in this case Lenovo had not made such an unqualified commitment but that it "shows that there are aspects of French law not explored before Meade J". 106

As a result of this, the judge turned to considering evidence on French law to assess whether Lenovo established that its argument "goes to a point of substance". ${ }^{107}$ Note that there was also evidence on Chinese and US law (other jurisdictions involved in the dispute) but the judge found these to be "peripheral", whereas the French law evidence went directly to whether an injunction was appropriate. $^{108}$

Lenovo's expert had argued that even if an implementer refused to take a FRAND licence and does so in bad faith, the only remedy available to a SEP owner in French law is damages and not an injunction, irrespective of whether there is one or more fora available to settle a global licence. Interdigital's expert had been directed not to address Lenovo's expert's interpretation of the ETSI IPR Policy. ${ }^{109}$ Nevertheless, HHJ Hacon concluded that Lenovo's principal point was that its

\footnotetext{
102 Supra note 100, [6].

103 Supra note 100, [23].

104 Supra note 100, [30]-[45].

105 Supra note 100, [44]-[45].

106 Supra note 100, [45].

107 Supra note 100, [46]-[57].

108 Supra note 100, [46].

109 Supra note 100, [53], [55].
} 
application raised new points of French law that had not been considered by Meade $\mathrm{J}$ in Optis. ${ }^{110}$

The judge concluded that Meade J had appeared to accept that the implementer's obligation to take a FRAND licence was "hard-edged" but that that view was taken in the context of the facts of the Optis case, in which the English court was the only tribunal under consideration for the settlement of the licence terms. Meade $\mathrm{J}$ had not made a ruling that the obligation was "hard-edged" in requiring the implementer to invariably commit to FRAND terms settled by the court in which the finding of infringement of one patent in the portfolio has been made (or, as HHJ Hacon said to be seen another way, "the court preferred by the SEP owner"). ${ }^{111}$

The judge held that the effect of French law when an implementer refuses to commit to take a FRAND licence on terms settled by the SEP owner's preferred tribunal but where it gives an unqualified undertaking to license on terms settled by another tribunal with jurisdiction had not been considered by the English courts (or any other). ${ }^{112}$ However, the judge said that this was not what this case was about as the commitment offered by Lenovo was vaguely qualified. Nonetheless, the judge held that it was not possible to say "unarguably" that under French law Lenovo's commitment disqualifies them from the benefit of relying on Interdigital's ETSI undertaking. The judge concluded that " $[\mathrm{t}]$ his is a matter which can only be decided after cross-examination of the experts and full argument" and accordingly he dismissed Interdigital's application. ${ }^{113}$

\section{Illumina Cambridge Ltd v. Latvia MGI Tech SIA \& Ors}

Lastly, in Illumina Cambridge Ltd v. Latvia MGI Tech SIA \& Ors ${ }^{114}$ the Court of Appeal gave us a judgment in this case just before the end of the year. Here, the Court of Appeal upheld Birss J's (as he then was) first instance decision that four patents owned by Illumina were valid and infringed by MGI (a fifth patent was held to be invalid at first instance but this was not subject to the appeal). ${ }^{115}$

The patents subject to the appeal fell into two groups: (i) three patents known as the "Modified Nucleotide Patents", which claimed priority from a British application referred to as "P2"; and (ii) the 415 Patent. ${ }^{116}$

MGI contended that the Modified Nucleotide Patents could not be both nonobvious over prior art, known as "Zavgorodny", and entitled to priority from P2. At the trial, MGI's primary case was that the Modified Nucleotide Patents were obvious and priority was run as a squeeze. MGI's primary case on appeal was that Birss J's reasoning on priority was inconsistent with his reasoning on obviousness

\footnotetext{
${ }^{110}$ Supra note 100, [57].

111 Supra note 100, [60].

112 Supra note 100, [61].

113 Supra note 100, [62].

114 [2021] EWCA Civ 1924; [2021] 12 WLUK 235.

115 [2021] EWHC 57 (Pat); [2021] 1 WLUK 158.

116 Supra note 114, [2].
} 
and that he ought to have concluded that the patents were not entitled to priority. Or, alternatively, if the judge was right on priority then he was wrong on obviousness. ${ }^{117}$

MGI's appeal relating to the Modified Nucleotide Patents was rejected. ${ }^{118}$ Arnold LJ, who gave the leading judgment, agreed with Birss $\mathrm{J}$ below that there was no squeeze between obviousness and priority in this case. ${ }^{119}$ He further held that even though MGI pleaded a case of AgrEvo obviousness, the case it ran and the case on appeal was a conventional case of obviousness over Zavgorodny, which it was held did not point the skilled team towards the claimed inventions. ${ }^{120}$

Lastly, Arnold LJ stated that MGI did not clearly argue that the Modified Nucleotide Patents were not entitled to priority because P2 did not make it plausible that the claimed compounds would have the claimed utility. But, even if it had made this argument more clearly, Birss $\mathrm{J}$ would have been correct to reject it. ${ }^{121}$

With respect to the 415 Patent, Birss $\mathrm{J}$ had found that Claim 1 combined two elements that when taken on their own were obvious but when combined were not obvious. However, he said that if this was a collocation then it would be invalid. ${ }^{122}$

Arnold LJ provided an extensive review of the law on collocation and the EPO Examination Guidelines on this issue. ${ }^{123} \mathrm{He}$ held that MGI's appeal on this issue should also be dismissed, stating: "I agree with the judge that, even assuming that the collocation principle is applicable to an invention consisting of a class of molecules, the application of the principle must take account of that technical context." He concluded that the 415 Patent claimed a single invention that made a technical contribution to the art. ${ }^{124}$

As such, the Court of Appeal rejected MGI's appeal in its entirety and upheld the first instance validity finding of the four patents subject to the appeal. A fifth patent had been held invalid at first instance but this finding was not appealed. Interestingly, at first instance, Birss $\mathrm{J}$ had made some findings about the concept of "Regeneron ranges", ${ }^{125}$ i.e. the requirement to show that an invention is enabled across the scope of a claim applies only to a relevant range. Birss $\mathrm{J}$ had held that being relevant in a Regeneron sense was dependent on all the circumstances, not just the claim as drafted but also "the essence or core of the invention (closely related to the technical contribution and/or inventive concept)". ${ }^{126}$ At first instance, the ranges put forward by MGI as rendering the patent insufficient were not held to be relevant ranges and therefore did not render the patent insufficient as they did not

\footnotetext{
117 Supra note 114, [63].

118 Supra note 114, [117].

119 Supra note 114, [113].

120 Supra note 114, [114].

121 Supra note 114, [115]-[116].

122 Supra note 115, [510] et seq.

123 Supra note 114, [157]-[169].

124 Supra note 114, [173].

125 Arising from the decision of Regeneron Pharmaceuticals Inc v. Kymab Ltd [2020] UKSC 27; [2021] 1 All ER 475. Covered previously in last year's review, see https://doi.org/10.1007/s40319-021-01036-y. 126 Supra note 115, [277].
} 
go to the essence of the invention. The decision allayed some concerns expressed after Regeneron that the English courts might be more willing to find patents insufficient. It would have been nice to hear the Court of Appeal's judgment on this point; however, as Birss J's insufficiency findings were not appealed this matter was not considered by the court. It will be interesting to see whether Birss J's findings on "Regeneron ranges" are returned to at a later date.

This review article has sought to provide a brief overview of some of the most interesting patent decisions of 2021. Although, of course, there were many more cases that could not be covered. The following year looks set to be another active year in the world of patents, with SEPs and FRAND due to take centre stage again. We eagerly await to see what the next year holds...

Open Access This article is licensed under a Creative Commons Attribution 4.0 International License, which permits use, sharing, adaptation, distribution and reproduction in any medium or format, as long as you give appropriate credit to the original author(s) and the source, provide a link to the Creative Commons licence, and indicate if changes were made. The images or other third party material in this article are included in the article's Creative Commons licence, unless indicated otherwise in a credit line to the material. If material is not included in the article's Creative Commons licence and your intended use is not permitted by statutory regulation or exceeds the permitted use, you will need to obtain permission directly from the copyright holder. To view a copy of this licence, visit http:// creativecommons.org/licenses/by/4.0/.

Publisher's Note Springer Nature remains neutral with regard to jurisdictional claims in published maps and institutional affiliations. 